Racic M, Todorovic R, Ivkovic N, Masic S, Joksimovic B, Kulic M. Self-perceived stress in relation to anxiety, depression and health-related quality of life among health professions students: a cross-sectional study from Bosnia and Herzegovina. Zdr Varst 2017; 56(4): 251-259.

\title{
SELF- PERCEIVED STRESS IN RELATION TO ANXIETY, DEPRESSION AND HEALTH-RELATED QUALITY OF LIFE AMONG HEALTH PROFESSIONS STUDENTS: A CROSS-SECTIONAL STUDY FROM BOSNIA AND HERZEGOVINA SAMO-ZAZNAVA STRESA V POVEZAVI Z ANKSIOZNOSTJO, DEPRESIJO IN Z ZDRAVJEM POVEZANO KAKOVOSTJO ŽIVLJENJA MED ŠTUDENTI ZDRAVSTVENIH VED: PRESEČNA ŠTUDIJA IZ BOSNE IN HERCEGOVINE
}

\author{
Maja RACIC ${ }^{1 *}$, Radica TODOROVIC ${ }^{2}$, Nedeljka IVKOVIC ${ }^{1}$, Srdjan MASIC ${ }^{1}$, Bojan JOKSIMOVIC ${ }^{1}$, Milan KULIC \\ ${ }^{1}$ University of East Sarajevo, Faculty of Medicine, Department for PC and Public Health, \\ Studentska 5, 73300 Foca, Bosnia and Herzegovina \\ ${ }^{2}$ Health Center Han Pijesak, Bosnia and Herzegovina
}

\section{ABSTRACT}

Keywords: assessment, stress, anxiety, students, quality of life

\section{IZVLEČEK}

Ključne besede:

ocena, stres, anksioznost, študenti, kakovost življenja
Introduction. The purpose of the present study was to examine self-perceived stress of health professions students at the Faculty of Medicine Foča, and to explore its association with anxiety, depression and healthrelated quality of life.

Methods. The cross-sectional study enrolled 451 students at the Faculty of Medicine (medicine, dentistry, nursing and speech therapy). Survey instruments were distributed at the conclusion of the spring semester during the last required lecture for each year and study programme class. Perceived stress was assessed using the 14-item Perceived Stress Scale. The students were evaluated for symptoms of depression and anxiety, using Zung's self-assessment inventory for depression and the Spielberger State-Trait Anxiety Inventory (STAI). European Quality of Life-5 dimensions were used for describing and evaluating health. Multivariate analyses were carried out using logistic regression to examine the relationship between the outcome variable and selected determinant factors.

Results. A high degree of stress was reported by $1.6 \%$ of students, while the majority of students had either moderate $(70.6 \%)$ or low degree $(27.5 \%)$ of stress. The significant independent factors associated with perceived stress were anxiety score (OR, 0.339; CI 95\%, 0.276-0.403) and EQ-5D score (OR, 0.044; CI 95\%, 0.033-0.085). A high degree of perceived stress (OR, 0.624; $\mathrm{Cl} 95 \%, 0.507-0.704)$, the presence of depression (OR, 0.800; $\mathrm{Cl} 95 \%$, $0.513-1.087)$, and low quality of life were associated with anxiety (OR, 0.073; $\mathrm{Cl} 95 \%, 0.018-0.128)$.

Conclusion. Higher levels of perceived stress predispose health professions students for anxiety and lower quality of life. The study programme was not a significant determinant of perceived stress sore.

Uvod. Namen študije je bil preučiti samo-zaznan stres študentov zdravstvenih ved na Medicinski fakulteti Foča in raziskati njegovo povezavo z anksioznostjo, depresijo in z zdravjem povezano kakovostjo življenja.

Metode. Presečna študija je vključevala 451 študentov Medicinske fakultete (medicina, zobozdravstvo, zdravstvena nega in govorna terapija). Raziskovalna orodja so bila razdeljena ob koncu spomladanskega semestra med zadnjimi obveznimi predavanji za vsak letnik in študijski program. Zaznan stres je bil ocenjen $\mathrm{z}$ uporabo 14-stopenjske lestvice za zaznavanje stresa. Med študenti smo ocenili simptome depresije in aksioznosti z uporabo Zungovega vprašalnika za samooceno depresije in orodja Spielbergerjevega vprašalnika za oceno anksioznosti (STAI). Za opis in vrednotenje zdravja so bili uporabljeni vprašalniki o kakovosti življenja EQ-5D. Za proučevanje povezav med spremenljivko izidov in izbranimi determinantami so bile izvedene multivariatne analize z uporabo logistične represije.

Rezultati. O visoki stopnji stresa je poročalo 1,6\% študentov, medtem ko je večina študentov poročala o srednji $(70,6 \%)$ ali nizki $(27,5 \%)$ stopnji stresa. Pomembni neodvisni dejavniki, ki so bili povezani z zaznavanjem stresa, so bili rezultati vprašalnika o anksioznosti (OR 0,339; Cl 95\%, 0,276-0,403) in rezultati vprašalnika EQ-5D (OR 0,044; Cl 95\%, 0,033-0,085). Visoke stopnje zaznanega stresa (OR 0,624; Cl 95\%, 0,507-0,704), prisotnost depresije (OR 0,800; Cl 95\%, 0,513-1,087) in slaba kakovost življenja so bili povezani z anksioznostjo (OR 0,073; $\mathrm{Cl} 95 \%, 0,018-0,128)$.

Zaključek. Višje stopnje zaznanega stresa so predispozicija za anksioznost in nižjo kakovost življenja študentov zdravstvenih ved. Študijski program ni bil bistvena determinanta za zaznavanje stopnje stresa. 


\section{INTRODUCTION}

The beginning of university life represents an important period of transition from adolescence to young adulthood that could be very often difficult due to interactions between individual psychological characteristics and common stressors, such as academic demands, changes in lifestyle, moving away from home, separating from family, inadequate living conditions, physical and emotional problems, and financial concerns (1-3). Stress in university students may also be related to examination (4), pressure of expectation to succeed or to be competitive, and an uncertain future $(5,6)$. Numerous studies analysed the correlation between exposure to aforementioned stressors and students' health $(7,8)$. It has been shown that stress has a significant, negative impact on overall health (79) and may cause mental problems, deleterious dietary changes (10) as well as generate poor coping skills leading to aggressive behaviour and somatic disorders (11).

Although it is not well-known whether health professions education differs from other higher education, it is generally considered as highly demanding, and students perceive it as a source of significant psychological and emotional distress (12-20).

Previous studies have shown that students who chose medical profession because they wish to help people have greater predisposition to the stress over the students driven by professional respect or material benefit (21). Besides being exposed to academic-related stress, caused by curriculum overload, constant assessments, little time available or variable hour shift for clinical rotations (22), health professions students also encounter occupational stress because they deal with people, their health and their lives. In order to reach the personal and professional maturity the health professions jobs require, the students partake of handling their own mind, attitudes or emotions, and coping with the stress in different, sometimes even difficult, clinical situations (23). Inadequate teaching methods or lack of mentor's support often unable students to adopt required skills, empathy and professionalism manners, ultimately leading to poor coping mechanisms and greater proneness to stress (24).

Increased perception of stress might be associated with moderate level of anxiety, depression symptoms, interpersonal sensitivity, frustration and powerlessness (25). When associated with anxiety and depression, occupational stress, as experienced by the student, can influence his or her quality of life and decrease his or her academic performance due to anxiety-induced difficult cognitive functioning, such as memory disorders, blockage, incapacity to make decisions, and increased sensitivity to appraisals of others $(26,27)$. Previous research found that the students and residents who frequently experience stress, also exhibit higher degree of burnout $(20,28)$ and future professional impairment (29).
As a psychological and physiological state, anxiety is considered to be a normal response to stress, but prolonged exposure and higher levels of perceived stress may lead to adverse consequences, including the development of anxiety disorder (30). When experiencing high levels of anxiety during their studies, the students are frequently inclined to achieve lower quality of total performance, which usually makes them feel that the situational demands exceed their competences, which further deepens perceived stress, ultimately resulting in the individual's psychological distress (31). Situational stress, showed to be a factor that elevates state anxiety, probably because students realise that they will be judged and that their achievements will be compared with the achievements of others. Highly trait-anxious students often experienced stronger state-anxiety compared to low trait-anxious students, which implies that students with anxiety tendencies are more predisposed to state anxiety in stressful situation (32).

Very little is known about perceived stress among health professions students in Bosnia and Herzegovina $(\mathrm{BiH})$, especially students of medicine. At the Faculty of Medicine, University of East Sarajevo, the study programme of medicine still has traditional curriculum. The students begin their training with three years of pre-clinical course, involving the basic medical sciences. This is followed by the three years of clinical courses and clinical rotations. Students attend lectures on all aspects of medical practice during the whole training. The programme is considered demanding, but up to now, aspects of study stress and generally students' health and behaviour have not yet been studied much (33).

The purpose of the present study was to examine perceived stress of students at the Faculty of Medicine Foča, and to explore its association with anxiety, depression, and health-related quality of life. The questions were formulated into the following hypothesis. The symptoms of depression and anxiety among undergraduate students are associated with perceived stress and self-perceived health. The perceived stress in students of medicine differs from that in the students of similar study programmes, such as dentistry, nursing, and speech language therapy.

\section{METHODS}

\subsection{Study Design and Participants}

The cross-sectional study was conducted in June 2015. Data were collected from 18-year-old students or older enrolled in one of four study programmes at the Faculty of Medicine (medicine, dentistry, nursing, speech therapy). All first-year through sixth-year students (fourth-year for nursing and speech therapy) were invited to participate in the study. Survey instruments were distributed at the conclusion of the spring semester during the last required 
lecture for each year and study programme class. The study was extensively introduced to students by research assistants. It was explained that the refusal to participate in the survey would have no academic consequences. Each student received a short description of research objectives and paper-and-pencil survey instruments. The survey instruments took approximately 15 minutes to complete. Responses were anonymous, but survey instruments and questionnaires were numbered and collated for data analysis.

Students were informed that by completing the questionnaire, they agreed to participate in the study. No incentives were provided.

Out of the total 640 invited students, 451 agreed to participate in the survey and complete questionnaires (response rate was 70.5\%). Twenty-five students were excluded from the analysis due to incompletely filled out questionnaire. Therefore, the final sample consisted of 426 students.

The study was conducted according to the principles of the Declaration of Helsinki.

\subsection{Instruments}

Age, gender, place of birth, financial status and social support were surveyed for social background.

Perceived stress was assessed using the 14-item Perceived Stress Scale (PSS) (34). The PSS consists of multiple choice questions and measures stressful experiences and responses to stress over the previous 4 weeks. Items used a 4-point Likert scale response format, ranging from 'never' (0) to 'very often' (4). Questions that relate negative events or responses were scored in reverse manner. Scores were obtained by averaging their responses to all the items of the scale. The results of the scores were compared with scores predetermined for the questionnaire, and were classified as low (15-28), moderate (29-42), and high degree of stress $(>43)$. Bosnian translation of the PSS was performed employing two independent interpreters. For both translations, cases of disagreement were resolved by the appropriate researchers, who were native speakers in Bosnian and had expertise in research methodology. Cronbach alpha value of 0.82 for PSS was found to be adequate.

For the assessment of depressive symptoms, the Zung self-rating depression scale was used. The scale consists of 20 questions that should be answered according to 4 statements (most of the time/always/rarely/never). The composite score ranges from 20 to 80 points. The results were compared with scores predetermined for the questionnaire, classifying depressive symptoms as mild (45 to 59 points); moderate (60-69 points); and severe $(\geq 70)$. The score ranging from 20 to 44 was considered normal (35).
The Spielberger State-Trait Anxiety Inventory (STAI) was used to evaluate anxiety symptoms. The STAI is composed of two different scales: one related to state anxiety (STAI-S) and the other to trait anxiety (STAI-T). The State Anxiety Scale evaluated a transitory emotional state characterised by subjective feelings that may vary in intensity over time (transient manifest feelings of insecurity.). The Trait Anxiety Scale measured anxiety proneness and tendency to perceive a wider range of situations as threatening (personality characteristic). There are 20 items in each scale that are answered on a 4-point Likert scale (36). Two subscales were scored separately. The results of the scores were compared with scores predetermined for the questionnaire, classifying the anxiety levels as low (20 to 34 points); moderate (3549 points); and high/serious ( $\geq 50)$.

European Quality of Life-5 dimensions (EQ-5D) was used for describing and evaluating health (37). The first part of EQ-5D describes five dimensions, namely: 1) mobility, 2) self-care, 3) usual activity, 4) pain/discomfort, and 5) anxiety/depression. For each dimension, there are three categories of answers; no problem (0), some problems (1) and severe problems (2). The composite score ranges from 0 to 10 points. The EQ Visual Analogue Scale (EQ-5D VAS) was used as a measure of general self-assessment of Health-Related Quality of Life (HRQoL). The students were asked to circle the best answers that apply to them on the scale from 0 (the worst health imaginable) to 100 (the best health imaginable).

\subsection{Statistical Analysis}

Data analysis was performed using the Software Package for Statistical Analysis - The IBM SPSS 21 (Chicago, IL, 2012). Differences between more than two groups were calculated using ANOVA. Multivariate analyses were carried out using logistic regression to examine the relationship between the outcome variable and selected determinant factors. Unadjusted odds ratios (OR) and their $95 \%$ confidence intervals $(\mathrm{Cl})$ were used as indicators of the strength of association. A p-value of 0.05 or less was used as the cut-off level for statistical significance.

\section{RESULTS}

The study involved 426 students with the mean age of $21.5 \pm 2.26$ years. Most students were female (69.2\%), born in an urban place $(75.8 \%)$, and had good financial status (86.9\%).

A high degree of stress was reported by $1.6 \%$ of students, while the majority of students had either a moderate (70.6\%) or low degree $(27.5 \%)$ of stress. There was a tendency toward higher stress ratings by female students, and this was statistically significant $(p=0.046)$. Statistically 
significant difference in degree of stress was also found between four study programmes. Students of medicine reported moderate and high degree of stress more frequently as compared to dentistry, speech therapy and nursing students $(p=0.035)$. No significant difference was detected in the perceived stress degree among different years of study $(p=0.313)$ (Table 1$)$.

The students with moderate and high perceived stress degree reported a significantly lower quality of life assessed by EQ-5D $(\mathrm{p}<0.001)$. However, statistical difference between the groups with low, moderate, and high degree of perceived stress was not found in general self-assessment of HRQoL, as measured with EQ-5D VAS $(\mathrm{p}=0.161)$ (Table 2).

We compared the frequency of depression symptoms in students with different perceived stress degrees. Only $16(3.7 \%)$ students scored positive for the presence of depression (mild), whereby the frequency of symptoms increased with the increase of the perceived stress degree $(p=0.019)$ (Table 2$)$. Females reported depression more frequently compared with their male counterparts $(p=0.042)$.

The majority of students reported either mild (50\%) or moderate (38\%) levels of trait anxiety. Similarly to depression symptoms, there was an apparent stepladder appearance in distribution of trait anxiety levels according to perceived stress degree $(p<0.001)$ (Table 2$)$.

The state scale was used to assess how students anticipate their feelings in a variety of hypothetical situations. Students with higher levels of stress scored higher in the Stale Anxiety Scale than the students with low stress levels $(p<0.001)$ (Table 2$)$. Unlike trait anxiety, none of the students reported state anxiety level as severe.

A weak, statistically significant correlation $(r=0.245$, $\mathrm{p}<0.001)$ was found between state and trait anxiety. Greater elevation of state anxiety was detected in moderate and severe trait-anxious students.

Table 1. Degree of perceived stress assessed by 14-item Perceived Stress Scale, depending on different characteristics of examined students.

\begin{tabular}{|c|c|c|c|c|}
\hline \multirow[b]{2}{*}{ Variable } & \multicolumn{3}{|c|}{ Perceived stress degree } & \multirow[b]{2}{*}{ P-value } \\
\hline & $\begin{array}{l}\text { Low } \\
\text { n (\%) }\end{array}$ & $\begin{array}{c}\text { Moderate } \\
\text { n (\%) }\end{array}$ & $\begin{array}{l}\text { High } \\
\text { n (\%) }\end{array}$ & \\
\hline \multicolumn{5}{|l|}{ Gender } \\
\hline Male & $46(39.3)$ & $84(28.8)$ & $1(14.3)$ & 0.046 \\
\hline Female & $71(60.7)$ & $218(71.2)$ & $6(85.7)$ & \\
\hline \multicolumn{5}{|l|}{ Study program } \\
\hline Medicine & $29(27.8)$ & $114(37.7)$ & $4(51.1)$ & 0.035 \\
\hline Dentistry & $46(39.3)$ & $73(24.2)$ & $2(28.6)$ & \\
\hline Speech therapy & $23(19.7)$ & $68(22.5)$ & $1(14.3)$ & \\
\hline Nursing & $19(16.2)$ & $47(15.6)$ & 0 & \\
\hline \multicolumn{5}{|l|}{ Year of study } \\
\hline $\mathrm{Y} 1$ & $41(35.0)$ & $120(39.7)$ & $1(14.3)$ & 0.313 \\
\hline $\mathrm{Y} 2$ & $24(20.5)$ & $78(25.8)$ & $3(42.9)$ & \\
\hline Y3 & $21(17.9)$ & $39(12.9)$ & 0 & \\
\hline Y4 & $11(9.4)$ & $21(7.0)$ & 0 & \\
\hline Y5 & $10(8.5)$ & $23(7.6)$ & $2(28.6)$ & \\
\hline Y6 & $10(8.5)$ & $21(7.0)$ & $1(14.3)$ & \\
\hline \multicolumn{5}{|l|}{ Place of birth } \\
\hline Urban & $91(77.8)$ & $226(74.8)$ & $6(85.7)$ & 0.892 \\
\hline Rural & $26(22.2)$ & $75(24.8)$ & $1(14.1)$ & \\
\hline \multicolumn{5}{|l|}{ Financial status } \\
\hline Good & 107 (91.5) & $258(85.4)$ & $5(71.4)$ & 0.125 \\
\hline Poor & $10(8.5)$ & $44(14.6)$ & $2(28.6)$ & \\
\hline \multicolumn{5}{|l|}{ Social support } \\
\hline Good & $116(99.1)$ & 292 (96.7) & $6(85.7)$ & 0.071 \\
\hline Poor & $1(0.9)$ & $10(3.3)$ & $1(14.3)$ & \\
\hline
\end{tabular}


Table 2. Perceived stress degree of examined students depending on quality of life, depression and anxiety symptoms.

\begin{tabular}{|c|c|c|c|c|}
\hline \multirow[b]{2}{*}{ Variable } & \multicolumn{3}{|c|}{ Perceived stress degree } & \multirow[b]{2}{*}{ P-value } \\
\hline & $\begin{array}{l}\text { Low } \\
\text { n (\%) }\end{array}$ & $\begin{array}{c}\text { Moderate } \\
\text { n (\%) }\end{array}$ & $\begin{array}{l}\text { High } \\
\text { n (\%) }\end{array}$ & \\
\hline \multicolumn{5}{|l|}{ EQ-5D } \\
\hline no problem & $99(34.3)$ & $190(44.6)$ & $3(0.7)$ & 0.001 \\
\hline light difficulties & $14(3.3)$ & $59(13.8)$ & $3(0.7)$ & \\
\hline moderate difficulties & $2(0.5)$ & $25(5.9)$ & 0 & \\
\hline severe difficulties & $2(0.5)$ & $15(3.5)$ & 0 & \\
\hline extreme difficulties & 0 & $13(3)$ & $5(1.1)$ & \\
\hline \multicolumn{5}{|l|}{ EQ-5D VAS } \\
\hline $0-40$ & $2(0.5)$ & $8(1.9)$ & 0 & 0.161 \\
\hline $41-70$ & $6(1.4)$ & $38(8.9)$ & 0 & \\
\hline $71-100$ & $109(25.6)$ & $256(60.1)$ & $7(1.6)$ & \\
\hline \multicolumn{5}{|l|}{ Depression } \\
\hline no problem & $117(20.5)$ & $287(67.4)$ & $6(1.4)$ & 0.019 \\
\hline mild & 0 & $15(3.5)$ & $1(0.2)$ & \\
\hline \multicolumn{5}{|l|}{ Trait anxiety } \\
\hline no problem & $10(2.3)$ & $1(0.2)$ & 0 & 0.001 \\
\hline mild & $97(22.8)$ & $116(27.2)$ & 0 & \\
\hline moderate & $10(2.3)$ & $149(35)$ & $3(0.7)$ & \\
\hline severe & 0 & $36(8.5)$ & $4(0.9)$ & \\
\hline \multicolumn{5}{|l|}{ State anxiety } \\
\hline no problem & $117(27.5)$ & $290(68.1)$ & $5(1.2)$ & 0.001 \\
\hline mild & 0 & $12(1.8)$ & $1(0.2)$ & \\
\hline moderate & 0 & 0 & $1(0.2)$ & \\
\hline
\end{tabular}

The multivariate linear regression analysis was used to find independent factors associated with the following outcome variables: perceived stress score, self-reported depression score, self-reported anxiety score, and HRQoL score. The results of the analysis presented in Tables 3 and 4 shows that the sociodemographic factors were not associated with any of analysed variables ( $p>0.05)$.

The significant independent factors associated with perceived stress were trait anxiety (OR, 0.339; $\mathrm{Cl} 95 \%$, $0.276-0.403, p<0.001)$ and EQ-5D score $(O R, 0.044 ; \mathrm{Cl}$ $95 \%, 0.033-0.085, p=0.036$ ). The presence of anxiety was the only significant determinant of depression score (OR, 0.085; Cl 95\%, 0.054-0.115, $\mathrm{p}<0.001$ ) (Table 3). EQ-5D score was associated with perceived stress degree (OR, 0.243; $\mathrm{Cl} 95 \%, 0.16-0.467, \mathrm{p}=0.036)$ and high trait anxiety level (OR, 0.220; Cl 95\%, 0.053-0.386, $\mathrm{p}=0.010$ ). Poor general health assessment was a risk factor for healthrelated quality of life (OR, $-0.604 ; \mathrm{Cl} 95 \%,-0.833-0.374$, $p<0.001)$. 
Table 3. Factors associated with perceived stress, depression, and HRQoL score (Multivariate linear regression analysis).

\begin{tabular}{|c|c|c|c|c|c|c|}
\hline \multirow[b]{2}{*}{ Factor } & \multicolumn{2}{|c|}{ Perceived stress score* } & \multicolumn{2}{|l|}{ Depression+ } & \multicolumn{2}{|c|}{ Health-related quality of life ${ }^{\circ}$} \\
\hline & $\begin{array}{c}\text { OR } \\
(95 \% \mathrm{Cl})\end{array}$ & $\mathbf{P}$ & $\begin{array}{c}\text { OR } \\
(95 \% \mathrm{Cl})\end{array}$ & $\mathbf{P}$ & $\begin{array}{c}\text { OR } \\
(95 \% \mathrm{Cl})\end{array}$ & P-value \\
\hline Gender & $0.076(-0.012-0.165)$ & 0.091 & $0.033(-0.007-0.072)$ & 0.102 & $-0.150(-0.035-0.059)$ & 0.160 \\
\hline Age & $0.019(-0.098-0.192)$ & 0.524 & $0.05(-0.10-0.21)$ & 0.515 & $-0.315(-0.654-0.025)$ & 0.069 \\
\hline Study program & $0.019(-0.021-0.59)$ & 0.352 & $-0.002(-0.20-0.015)$ & 0.803 & $-0.014(-0.108-0.079)$ & 0.764 \\
\hline Study year & $-0.017(-0.065-0.032)$ & 0.507 & $-0003(-0.024-0.019)$ & 0.803 & $0.042(-0.073-0.157)$ & 0.475 \\
\hline Place of birth & $0.002(-0.36-0.40)$ & 0.920 & $-0.004(0.092-0.021)$ & 0.617 & $0.023(-0.67-0.112)$ & 0.618 \\
\hline Financial status & $0.012(-0.116-0.139)$ & 0.858 & $-0.035(-0.21-0.12)$ & 0.215 & $0.226(-0.075-0.525)$ & 0.139 \\
\hline Social support & $0.054(-0.201-0.309)$ & 0.678 & $-0.023(-0.089-0.136)$ & 0.686 & $0.067(-0.533-0.668)$ & 0.826 \\
\hline Perceived stress & - & & $-0.015(-0.058-0.027)$ & 0.481 & $0.243(0.16-0.467)$ & 0.036 \\
\hline Depression & $-0.078(-0.297-0.140)$ & 0.481 & - & - & $0.218(-0.297-0.734)$ & 0.405 \\
\hline Trait anxiety & $0.339(0.276-0.403)$ & 0.000 & $0.85(0.054-0.115$ & 0.000 & $0.220(0.053-0.386)$ & .010 \\
\hline EQ-5D score & $0.044(0.033-0.085)$ & 0.036 & $0.008(-0.010-0.026)$ & 0.405 & - & - \\
\hline EQ-5D VAS score & $0.87(-0.013-0.187)$ & 0.089 & $-0.36(-0.88-0.009)$ & 0.115 & $-0.604(-0.833-0.374)$ & .000 \\
\hline
\end{tabular}

P-value $<0.05$ is considered significant and bolded.

*Wald Chi-square=71.546, $p<0.001$; based on $n=393$ observations; SE $(0.242)$

+Wald Chi-square=19.606, $p<0.001$; based on $n=225$ observations; SE $(0.334)$

${ }^{\circ}$ Wald Chi-square=128.627, $p<0.001$; based on $n=426$ observations; SE $(0.135)$

A high degree of perceived stress (OR, 0.624; $\mathrm{Cl} 95 \%$, $0.507-0.704, p<0.001)$, the presence of depression (OR, $0.800 ; \mathrm{Cl} 95 \%, 0.513-1.087, \mathrm{p}<0.001)$, and low quality of life were predictors of the trait anxiety $(\mathrm{OR}, 0.073 ; \mathrm{Cl}$ $95 \%, 0.018-0.128, p=0.020)$. State anxiety was a strong risk factor for trait anxiety (OR, 0.046; Cl 95\%, -0.0840.007, $\mathrm{p}<0.001$ ).
Perceived stress degree had a significant impact on the state anxiety level (OR, 0.696; Cl 95\%, 0.579-0.812, $\mathrm{p}<0.001$ ) among Bosnian health professions students. A significant association was found between trait and state anxiety score (OR, -0.351 ; CI95\%, $-0.546--0.157, \mathrm{p}=0.002)$.

Table 4. Factors associated with trait and state anxiety score (Multivariate linear regression analysis).

\begin{tabular}{|c|c|c|c|c|}
\hline \multirow[b]{2}{*}{ Factor } & \multicolumn{2}{|c|}{ Perceived stress score* } & \multicolumn{2}{|l|}{ Depression+ } \\
\hline & $\begin{array}{c}\text { OR } \\
(95 \% \mathrm{Cl})\end{array}$ & $\mathbf{P}$ & $\begin{array}{c}\text { OR } \\
(95 \% \mathrm{Cl})\end{array}$ & $\mathbf{P}$ \\
\hline Gender & $0.56(-0.065-0.176)$ & 0.365 & $0.061(-0.032-0.003)$ & 0.171 \\
\hline Age & $-0.003(-0.051-0.045)$ & 0.822 & $-0.015(-0.026-0.148)$ & 0.103 \\
\hline Study program & $0.039(-0.093-0.015)$ & 0.157 & $0.022(-0.108-0.079)$ & 0.256 \\
\hline Perceived stress & $0.624(0.507-0.740)$ & 0.000 & $0.696(0.579-0.812)$ & 0.000 \\
\hline Depression & $0.800(0.513-1.087)$ & 0.000 & $-0.081(-0.298-\quad 0.137)$ & 0.466 \\
\hline Trait Anxiety & - & - & $-0.351(-0.546--0.157)$ & 0.002 \\
\hline State Anxiety & $-0.046(-0.084-0.007)$ & 0.020 & - & - \\
\hline EQ-5D score & $-0.240(-0.375-0.106)$ & 0.000 & $-0.018(-0.009-0.046)$ & 0.187 \\
\hline
\end{tabular}

$\mathrm{P}$-value $<0.05$ is considered significant and bolded.

+Wald Chi-square=392.26, $p<0.001$; SE (0.133)

*Wald Chi-square=256.76, $p=0.006$; SE (0.175) 


\section{DISCUSSION}

The current study was conducted to assess the perceived stress and its association with anxiety, depression, and HRQoL in health professions students. As presented in Table 2, the majority of students perceived moderate stress $(70.6 \%)$ and only $1.6 \%$ of them perceived a high degree of stress. This is consistent with the results of other studies demonstrating that university students around the globe are exposed to high levels of stress $(38,39)$. The reported prevalence of perceived stress among health professions students ranged from $31.2 \%$ in the United Kingdom (12) to $83.9 \%$ in Australia (39). This difference in the prevalence between the countries is considered to be the result of culturally different perception of stress or stressful event, but also of environmental factors, such as economic burden of studying, very high tuition fees, lack of family support, and higher or lower 'readiness' to report the stress or any other complaint (7).

Perceived stress was significantly associated with anxiety levels in the current study (Table 3 and 4), and was an independent determinant of both, state and trait anxiety. This is in line with the study of Bunevicius et al., showing independent association of anxiety symptoms with higher vulnerability to stress and lower level of emotional stability in medical students (40). High, significant correlation between perceived stress and anxiety level was also found in the study of Heinen at al., conducted on the sample of 385 first-year medical students (19), as well as in the studies carried out among dentistry (41) and nursing students (42). High trait-anxiety could have led to greater sensitivity to stress because of students' attention being aimed toward threats to self-worth and self-esteem (43), while negative relationship between state and trait anxiety might have exacerbated the encumbrance of manifest anxiety (32). The results of the aforementioned research emphasise that counselling focusing on anxiety during health profession education might be a possible option for stress reduction. The autogenous training and progressive muscle relaxation showed to be effective in reducing trait and state anxiety levels in medical students (44).

Although ANOVA analysis showed that the frequency of depression symptoms increased with the increase of stress (Table 2), the association between self-rated depression and perceived stress was not found, as presented in Table 3. This is contrary to several other studies reporting very strong associations between these two outcome variables $(10,26,45)$. However, merely $3.7 \%$ of students examined here fulfilled the criteria for self-rated depression, in all cases it was rated as mild, which could explain why depression was not found to be the determinant of perceived stress.
A strong association was found between trait anxiety and depression score (Tables 3 and 4). Living in a constant state of anxiety can make the individual feel there is no hope for ever getting better and that life is not good, which creates a direct path to depression. Having depression during undergraduate studies can cause academic, psychosocial, physical, or academic related hindrances, as it is has been previously detected (46).

Regarding the role of quality of life, its relatedness to perceived stress, trait anxiety, and self-assessment of general health was demonstrated in the current study (Table 3). A portrait of stress levels and HRQoL has been provided in previous analyses, accentuating that higher vulnerability to stress in health professions students may be a predisposing risk factor for mental distress and poor physical heath (47). Our findings further support the necessity of providing predisposed students with programmes to alleviate their stress and boost their overall health (47).

ANOVA analysis showed higher levels of perceived stress in females than in males, and in medical students than in those of other programmes (Table 2). However, in a multivariate regression analysis neither gender nor study programme appeared as significant independent factors associated with perceived stress (Table 3 ). No association between gender and perceived stress was also reported in studies from Norway (48) and Germany (49), but studies from Sweden (14), Ethiopia (45), and Middle East (50) reported gender difference regarding stress perception. Different results in the studies may be subjected to a different degree of female discrimination, community pressure, and cultural habits.

The perceived stress in students of medicine did not differ from that in the students of dentistry, nursing, and speech language therapy. Controversial results were published on the relationship between health professions programmes of study and students' stress perception. Some found higher incidence of stress in medical students than in dental and nursing students (51), but the other reported lower stress levels in medical than in dental students (52, 53). These inconsistent findings indicate that in addition to the study programme, there are other independent factors that might increase one's proneness to stress.

\subsection{Limitations of the Study}

The current study has several limitations. The results may not be generalised, as the study was conducted in health professions students of one faculty of medicine, the socio-demographic structure of which was not necessarily the same as at the other faculties in Bosnia and Herzegovina. This was a cross-sectional study that assessed perceived stress degree of students at one point 
in time. The association between stress and academic performance was not analysed, although it would be interesting and important. Future research should be directed towards identifying personal and occupational stressors that contribute the most to the stress, as well as possible intervention to help students cope with them better. Longitudinal study through study years could show changes in perceived stress over time. Studies to identify factors that may mediate the relationship between perceived stress and depression in health professions students have to be conducted.

\subsection{Study Implications}

Decision-makers in academic programmes should focus more on students' well-being and provision of counselling services, which could help the students to effectively cope with, and manage the stress. These programmes will provide the opportunity to identify the students who are at greatest risk for psychological maladjustment during undergraduate training, and protect them against negative effects of stress, such as development of anxiety or depression.

Less stressful learning environment should be created, and help-seeking behaviour promoted. Starting a highimpact mentoring programme could potentially improve social support and affect perceived stress levels. Medical education should encourage resilience against stress, by increasing and maintaining empathy throughout whole undergraduate studies $(54,55)$.

\section{CONCLUSION}

Higher levels of perceived stress predispose students for anxiety and lower HRQoL. Although medical students reported higher levels of stress compared to the students of dentistry, nursing, and speech language therapy, the study programme was not a significant determinant of perceived stress score. The screening of stress among health professions students should become a regular practice, and those students experiencing high levels of stress should be undergoing screening for anxiety and depression. Interconnection of stress, trait and state anxiety, and HRQoL merits further investigation and development of appropriate interventions.

\section{ACKNOWLEDGMENT}

The authors wish to thank Prof. Ljubica Dukanović for editing the text.

\section{CONFLICTS OF INTEREST}

The authors declare that no conflicts of interest exist.

\section{FUNDING}

No funding has been received for the conduction of this study and preparation of the manuscript.

\section{ETHICAL APPROVAL}

The research protocol was approved for each survey by the Ethical Committee of the Faculty of Medicine Foča. All personal data were anonymised.

\section{REFERENCES}

1. Baumann M, lonescu I, Chau N. Psychological quality of life and its association with academic employability skills among newly registered students from three European faculties. BMC Psychiatry 2011; 11: 63 .

2. Legleye S, Beck F, Peretti-Watel P, Chau N, Firdion JM. Suicidal ideation among French young adults: association with occupation, family, personal background and drug use. J Affect Disord 2010; 123: 108-15.

3. Nock MK, Borges G, Bromet EJ, Alonso J, Angermeyer M, Beautrais A et al. Cross-national prevalence and risk factors for suicidal ideation, plans and attempts. Br J Psychiatry 2008; 192: 98-105.

4. Murphy L, Denis R, Ward CP, Tartar JL. Academic stress differentially influences perceived stress, salivary cortisol, and immunoglobulin-A in undergraduate students. Stress 2010; 13: 365-70.

5. Chew-Graham CA, Rogers A, Yassin N. 'I wouldn't want it on my CV or their records'medical students' experiences of help-seeking for mental health problems. Med Educ 2003; 37: 873-80.

6. Yusoff MS, Abdul Rahim AF, Baba AA, Ismail SB, Mat Pa MN, Esa AR. Prevalence and associated factors of stress, anxiety and depression among prospective medical students. Asian J Psychiatr 2013; 6: 128 33.

7. El Ansarni W, Oskrochi R, Haghgoo G. Are students' symptoms and health complains associated with perceive stress at the university?: perspectives from United Kingdom and Egypt. Int J Environ Res Public Health 2014; 11: 9981-10002.

8. Sundblad GB, Jansson A, Saartok T, Renstrom P, Engstrom LM. Selfrated pain and perceived health in relation to stress and physical activity among school-students: a 3-year follow-up. Pain 2008; 136 : 239-49.

9. Piko B, Piczil M. Study of stress, coping and psychosomatic health among baccalaureate nurses to-be. Orv Hetil 2012; 153: 1225-33.

10. Eisenberg D, Speer N, Hunt JB. Attitudes and beliefs about treatment among college students with untreated mental health problems. Psychiatr Serv 2012; 63: 711-13.

11. Niemi SM, Levoska S, Rekola KE, Keinanen-Kiukaanniemi S. Neck and shoulder symptoms of high school students and associated psychosocial factors. J Adolesc Health 1997; 20: 238-42.

12. Firth-Cozens J. Medical students stress. Med Educ 2001; 35; 6-7.

13. Jeong Y, Kim JY, Ryu JS, eun Lee K, Ha EH, Park H. The association between social suport, health-relatedbehaviors, socioeconomic status and depression in medical students. Epidemiol Health 2010; 32: e2010009. 
14. Dahlin M, Joneborg N, Runeson B. Stress and depression among medical students: a cross-sectional study. Med Educ 2005; 39: 594604.

15. Rahimi B, Baetz M, Bowen R, Balbuena L. Resilience, stress, and coping among Canadian medical students. Can Med Educ J 2014; 5: e5-12.

16. Matheson KM, Barrett T, LandineB, Alan McLuckie, Li-WehSoh N, Walter $\mathrm{G}$. Experiences of psychological distress and sources of stress and support during medical training: a survey of medical students. Acad Psychiatry 2016; 40: 63-8.

17. Sandover S, Jonas-Dwyer D, Marr T. Graduate entry and undergraduate medical students study approaches, stress levels and ways of coping: a five year longitudinal study. BMC Med Educ 2015; 15: 5.

18. Ludwig AB, Burton W, Weingarten J, Milan F, Kligler B. Depression and stress amongst undergraduate medical students. BMC Med Educ 2015; 15: 141-5.

19. Heinen I, Bullinger $M$, Kocalevent RD. Perceived stress in first year medical students - associations with personal resources and emotional distress. Med Educ 2017; 17: 4.

20. Krokter Kogoj T, Cebasek-Travnik Z, Zaletel-Kragelj L. Role of stress in burnout among students of medicine and dentistry - a study in Ljubljana, Slovenia, Faculty of Medicine. Coll Antropol 2014; 3: 879-87.

21. Crumpei I, Dafinoiu I. Secondary traumatic stress in medical students. Procedia Soc Behav Sci 2012; 46: 1465-9.

22. Kuhn L, Kranz PL, Koo F, Cossio G, Lund NL. Assessment of stress in physician assistant students. J Instruct Psych 2005; 32: 167-77.

23. Nechita F, Strba CT, Vere CC, Nechita D, Rogoveanu I. Stress in Romanian first year nursing students. Curr Health Sci J 2014; 40: 210-13.

24. Firth J. Levels and sources of stress in medical students. Br Med J (Clin Res Ed) 1986; 292: 1177-80.

25. Firth J, Mamo C, Buttigieg R, Vassallo D, Azzopardi L. Psychological stress amongst Maltese undergraduate medical students. Int J Collab Res Internal Med Public Health 2012; 4: 840-9.

26. Mikolajzyk RT, Maxwell AE, Naydenova V, Meier S, El Ansari W. Depressive symptoms and perceived burdens related to being student: survey in three European countries. Clin Pract Epidemiol Ment Health 2008; 4: 19.

27. Nechita F, Nechita D, Prilog MC, Rogoveanu I. Stress in medical students. Rom J Morphol Embryol 2014; 55: 1263-6.

28. Selič P, Stegne Ignjatovic T, Klemens-Ketis Z. Burnout among Slovenian family medicine trainees: a cross sectional study. Zdrav Vest 2012; 81: 218-24.

29. Henning K, Ey S, Shaw D. Perfectionism, the impostor phenomenon and psychological adjustment in medical, dental, nursing and pharmacy students. Med Edu 1998; 932: 456-64.

30. Wiegner L, Hange D, Björkelund C, Ahlborg G Jr. Prevalence of perceived stress and associations to symptoms of exhaustion, depression and anxiety in a working age population seeking primary care - an observational study. BMC Fam Pract 2015; 16: 38.

31. Cohen S, Janicki-Deverts D, Miller GE. Psychological stress and disease. JAMA 2007; 298: 1685-7.

32. Meijer J. Stress in the relation between trait and state anxiety. Psychol Rep 2001; 88: 947-64.

33. Kulić M. Dvadeset godina Medicinskog fakulteta u Foči. Foča: Medicinski fakultet, 2013.

34. Cohen S, Kamarck T, Marmelstein R. A global measurement of perceived stress. J Health Soc Behav 1983; 24: 385-96.

35. Zung WW. A self-rating depression scale. Arch Gen Psychiatry 1965; 12: 63-70.

36. Spielberger CD, Gorsuch RL, Lushene R, Vagg PR, Jacobs GA. Manual for state-trait anxiety inventory. Palo Alto: Consulting Psychologist Press, 1983
37. The EuroQol Group. EuroQol - a new facility for the measurement of health-related quality of life. Health Policy 1990; 16: 199-208.

38. Stewart-Brown S, Evans J, Patterson J, Petersen S, Doll H, Balding $\mathrm{J}$ et al. The health of students in institutes of higher education: an important and neglected public health problem. J Public Health Med 2000; 22: 492.

39. Stallman HM. Psychological distress in university students: a comparison with general population data. Aust Psychol 2010; 45: 249-57.

40. Bunevicius A, Katkute A, Bunevicius R. Symptoms of anxiety and depression in medicalstudents and in humanities students: relationship with big-five personality dimensions and vulnerability to stress. IJSP 2008; 54: 494-501.

41. Harris M, Wilson JC, Holmes S, Radford DR. Perceived stress and well-being among dental hygiene and dental therapy students. $\mathrm{Br}$ Dent J 2017; 27, 222: 101-1.

42. Chernomas WM, Shapiro C. Stress, depression, and anxiety among undergraduate nursing students. Int J Nurs Educ Scholarsh 2013; 10.

43. Covington MV. Making the grade: a self-worth perspective on motivation and school reform. Cambridge, UK: Cambridge University Press, 1992.

44. Wild K, Scholz M, Ropohl A, Brauer L, Paulsen F, Burger PH. Strategies against burnout and anxiety in medical education - implementation and evaluation of a new course on relaxation techniques (Relacs) for medical students. PLoS One 2014; 9: e114967.

45. Madebo WE, Yosef TT, Tesfaye MS. Assessment of perceived stress level and associated factors among health care students at Debre Birehane University, North Shoa Zone of Amgara Region, Ethiopia. HCCR 2016; 4: 2

46. Pidgeon AM, McGrath S, Magya HB, Stapleton P, Lo BCY. Psychosocial moderators of perceived stress, anxiety and depression in university students: an international studies. Open J Soc Sci 2014; 2: 23-31.

47. Geslani GP, Gaebelein CJ. Perceived stress, stressors, and mental distress among doctor of pharmacy students. Soc Behav Pers 2013; 41: 1457-68.

48. Bramness JG, Fixdal TC, Vaglum P. Effect of medical school stress on the mental health of medical students in early and late clinical curriculum. Acta Psychiatr Scand 1991; 84: 340-5.

49. Kocalevent RD, Hinz A, Brahler E, Klapp BF. Regional and individual factors of stress experience in Germany: results of a representative survey with the perceived stress questionnaire (PSQ). Gesundheitswesen 2011; 73: 829-34.

50. Abdulghani HM, Al Kanhal AA, Mahmoud ES, Ponnamperuma GG, Alfaris EA. Stress and its effects on medical students: a crosssectional study at a college of medicine in Saudi Arabia. J Health Popul Nutr 2011; 29: 516-22.

51. Dutta AP, Pyles MA, Miederhoff PA. Stress in health professions students: myth or reality?: a review of the existing literature. J Natl Black Nurses Assoc 2005; 16: 63-8.

52. Birks Y, McKendree J, Watt I. Emotional intelligence and perceived stress in healthcare students: a multi-institutional, multiprofessional survey. BMC Med Educ 2009; 9: 61-7.

53. Murphy RJ, Gray SA, Sterling G, Reeves K, DuCette J. A comparative study of professional student stress. J Dent Educ 2009; 73: 328-37.

54. Park KH, Kim DH, Kim SK, Yi YH, Jeong JH, Chae J et al. The relationships between empathy, stress and social support among medical students. Int J Med Educ 2015; 6: 103-8.

55. Petek-Ster M, Selic P. Assessing empathic attitudes in medical students: the re-validation of the Jefferson Scale of Empathy student version report. Zdr Varst 2015; 54: 282-92. 